Ksenija Leban

Filozofska fakulteta, Ljubljana

\title{
A Survey of Internationalisms between Slovene and English
}

V članku avtorica obravnava internacionalizme med slovenščino in angleščino, pri čemer se naslanja na korpus 895 leksikalnih parov, ki se začnejo na L, in pokaže, da lahko le v omejenem številu preučevanih parov prepoznamo prave prijatelje, medtem ko v preostalih primerih nastane oblika lažnega prijateljstva.

The paper discusses the phenomenon of internationalisms between Slovene and English on the basis of a corpus comprising 895 lexical pairs beginning with the letter L, and shows that only a limited number of the analysed pairs can be regarded as true friends, while others result in false friendship of different types.

\section{Introduction}

Internationalisms are "words which are used internationally" (Ivir 1988: 93). The formerly prevalent opinion that these internationally used words represent the part of the lexicon that can be used by foreign-language users without reserve, for they not only share more or less the same form but also have the same meaning, has long been replaced with translators' and interpreters' warnings against these translation traps for the unwary or false friends as most of them are often referred to.

As Ivir points out, and the present analysis proves, total overlap between internationalisms that have entered two languages is only one of the possibilities. Moreover, only a limited number of internationalisms belong to true friends, and can be used by foreign-language users without falling into the trap of committing interlingual errors. Most of the internationalisms, however, result in false friendship, either on the semantic, morphological, phonological and/or orthographical level.

True friends are, strictly speaking, only those pairs of words of common origin with which total overlap on all the above-mentioned levels can be established. However, they also include pairs of words with which differences could be accounted for through language systems. Thus, for example, all the analysed Slovene lexemes ending in -acija, -ocija or -ucija correspond to English lexemes ending in -ation, -otion and -ution respectively (laktacija v. lactation, lokomocija v. locomotion and lokucija v. locution); all the analysed Slovene lexemes ending in -izacija correspond to English lexemes ending in -isation/-ization (legalizacija v. legalisation); and all the analysed Slovene verbs ending in -irati correspond to English verbs, formed through conversion from their respective nouns (lamentirati v. lament), while all the analysed Slovene verbs ending in -izirati correspond to English verbs ending in -ise/-ize (literarizirati v. literalise/literalize). Similarly, some language-system spelling patterns may be observed such as, for example, Slovene $-k t-,-g v$ - and $-v k$ - corresponding to the English -ct-, $-g u$ - and $-u k$ - respectively (laktacija v. lactation, lingvističen v. linguistic, levkom v. leucoma). 
Internationalisms not resulting in true friends form the false-friend group. False friends between Slovene and English ${ }^{1}$ can be described as pairs of words of non-native origin which have preserved their foreign-looking and/or -sounding form in the Slovene language, and perhaps in the English language as well, and in which the misleading relationship between meaning and/or form may induce interlingual errors.

False friends included in the sample were studied strictly from the synchronic point of view. This means that only the differences existing today were taken into account. Therefore, with pairs of different morphological structure, it did not matter whether a particular lexeme had been adopted into one of the languages concerned with its affix or not, or if the affix in question was productive in the relevant language or not. The analysis was concerned exclusively with present differences between the lexemes. Thus lantan v. lanthanum, for example, belongs to the category of morphological false friends although the suffix $-u m$ was never productive in English and the English language borrowed the lexeme together with its original suffix.

All the lexical pairs included in the corpus were analysed in detail to show the differences and similarities between the lexemes. Thus, on the basis of the definitions in Slovene and English monolingual dictionaries, possible differences in meaning between the representatives of lexical pairs were established first. All the pairs characterised by differences in meaning were then classified as semantic false friends. With the remaining pairs, the exception always being the so-called zero-equivalent false friends, only differences in the morphological structure, pronunciation and orthography were looked for. Pairs characterised by total overlap both in meaning and in form were then classified as true friends, while pairs characterised by morphological, phonological and orthographical differences were classified as morphological, phonological and orthographical false friends respectively. When differences in form proved to be systematic, and could therefore be attributed to language systems, lexical pairs were moved into the true-friend category.

\section{Internationalisms - A Corpus Analysis}

Internationalisms beginning with the letter $\mathrm{L}^{2}$ in Slovene and English were examined with a view to establish how significant the phenomenon of false friendship really is.

The Slovene corpus consists of internationalisms beginning with the letter $\mathrm{L}$ found in the only general monolingual dictionary of the Slovene language, the Slo-

\footnotetext{
${ }^{1}$ I believe the same elaboration could be applied to other language pairs, e.g., Croatian and English, perhaps even to any Slavonic language and English. Although my opinion is based on the similarities that I could notice when consulting literature on false friends between several Slavonic languages and English, it has, to my personal knowledge, not been supported by any comparative analysis.

${ }^{2}$ Edward L. Thorndike, on the basis of a study of the lexicon, divided the English alphabet into 105 approximately equal units, called blocks. The letter L occupies four blocks or almost 4 per cent of the English vocabulary. Since a considerable number of lexical items of foreign origin begin with this letter, it is assumed that internationalisms beginning with the letter $\mathrm{L}$ might be considered a representative sample.
} 
var slovenskega knjižnega jezika (1970-91), supplemented with the lexical items occurring in the Slovar tujk (1982) and the Leksikon Cankarjeve založbe (1994). The corpus, composed of 895 Slovene lexical items, was then completed with the English counterparts, provided the English language had any.

Once the corpus was finished, each Slovene lexeme was compared to its English counterpart in order to establish whether any differences, regarding the form and/or meaning, may be observed. This was done by comparing the information about the respective lexemes in the above-mentioned dictionaries and encyclopaedia for the Slovene language and in the Collins English Dictionary (1994), The New Shorter Oxford Dictionary (1993) and the Oxford English Dictionary (1989) ${ }^{3}$ for the English language. Whenever the information occurring in the above-mentioned lexicographical works proved insufficient or even questionable, other dictionaries were consulted, e.g., the Longman Dictionary of English Language and Culture (1992), the Tehniški metalurški slovar (1995) and the Veliki moderni poslovni slovar (1997).

On the basis of the dictionary information, ${ }^{4}$ it could be established whether the lexical pairs differed on the semantic, morphological, phonological and/or orthographical levels. When no divergences could be found or when they proved to reflect systematic differences between the two languages, lexical pairs were classified as true friends.

Often, lexical pairs differed on more than one level. A hierarchy of false friends was therefore developed. This partly reflects the conclusions of other analyses and definitions of false friends (Crystal 1987, Golobič 1988 and 1989, Granger and Swallow 1988, Hayward and Moulin 1984, Ivir 1968 and 1988, Limon 1983, Malone 1982, Partington 1993, Topalova 1997, Van Roey 1990 and Wełna 1977), and the results of the comparison of the lexical items included in the corpus. While analysing the above-mentioned lexemes, it could be observed that, with certain types of false friends, differences may occur on various levels. Semantic false friends, for example, may differ in meaning, morphology, pronunciation and spelling. With morphological false friends, the meanings of the lexemes are the same - the lexical pairs would differ in their morphological structure. Often, morphological differences would be

\footnotetext{
${ }^{3}$ All the above-mentioned English dictionaries are general monolingual dictionaries. The decision to use the Collins English Dictionary as the basis for the comparison with the information on the Slovene lexical items provided by the Slovar slovenskega knjižnega jezika, which was dictated by the fact that the Collins English Dictionary is considered to be one of the best dictionaries of the collegiate-size category and is constantly being revised, proved to have some disadvantages. Ideally, two unabridged dictionaries should serve as the basis of the analysis. Unfortunately, the only general monolingual dictionary of Slovene falls into the desk-size category. Therefore the amount of information included in the dictionary is by definition smaller than the amount found in a collegiate dictionary. It is possible that the results of the analysis and the respective conclusions would be different if two dictionaries of the same size had been consulted.

${ }^{4}$ Relying on dictionary information has certain drawbacks. First, the information included in the dictionary is not always reliable or up-to-date. Second, it is concerned only with a limited number of lemma properties, e.g., the pronunciation, meaning, grammatical behaviour, etc., while other aspects, pragmatical, for example, are usually neglected. Nevertheless, dictionaries represent the most objective sources and are comparable among each other. That is why dictionaries were consulted in order to discover the differences between the lexemes.
} 
accompanied by phonological and orthographical divergences as well. Finally, while with phonological false friends differences in pronunciation may be supported also by different spelling, divergences among orthographical false friends are restricted to orthography.

Zero-equivalent false friends represent a separate category, for, with this type of lexemes, false friendship is not caused by semantic, morphological, phonological or orthographical differences, but by the non-existence of a similar counterpart.

A possible hierarchy of internationalisms would then consist of true friends and zero-equivalent false friends representing the two opposite ends of the scale, with other types of false friends occurring in-between. Because they are treacherous, semantic false friends would appear closest to the zero-equivalent false-friend category. Semantic false friends would then be followed by morphological and phonological false friends, with orthographical false friends occurring closest to true friends.

\section{Figure 1. A hierarchy of internationalisms}

$$
\begin{aligned}
& \text { true friends } \\
& \text { orthographical false friends } \\
& \text { phonological false friends } \\
& \text { morphological false friends } \\
& \text { semantic false friends } \\
& \text { zero-equivalent false friends }
\end{aligned}
$$

On the basis of the differences between the analysed lexemes and the hierarchy proposed, false friends were classified as semantic, morphological, phonological, orthographical and zero-equivalent false friends respectively. False friends with which differences occurred on more than one level were classified according to the most treacherous of the divergences established within the lexical pair. Thus, semantic false friends which also differ in morphological structure, pronunciation and/or spelling are treated as semantic false friends, morphological false friends with treacherous pronunciation and/or orthography belong to the morphological false-friend category, and phonological false friends with which differences extend to spelling as well are referred to as phonological false friends.

Analysing the corpus and classifying true and false friends do not always produce the same results. First of all, the classification very much depends on the accuracy and refinement intended by the analyst. ${ }^{5}$ Second, the unstable meaning

${ }^{5}$ In her work, Magdalena Pregelj (1995) analyses Slovene internationalisms beginning with the letter A and compares them to the English ones. She claims to have found only 300 internat ionalisms, of which 200 were true friends. Unfortunately, however, she does not mention anything about the compilation of the corpus. Therefore it is practically impossible to speculate on the discrepancies between her analysis and mine. At first I thought that her analysis only comprised the lexemes of foreign origin in the Slovar tujk (1982), but the number of the lexemes beginning with 
with its fuzzy edges is very often hard to classify, especially if the individual classes are not as clear-cut as they should be. Third, the analysis of individual pairs is based on the information found in dictionaries. This poses several problems, the most serious ones being their reliability and comparability. As already mentioned, there exists only one general monolingual dictionary of Slovene, the compilation of which took the lexicographical team twenty years. This means that the dictionary does not register new words, new meanings and changes of meanings. Furthermore, the definitions and the illustrative material were taken from citation files and were not based on a corpus of Slovene as it is standard practice in the English-speaking countries nowadays. The analysis was also hindered by the size of the Slovar slovenskega knjižnega jezika, comparable to English desk dictionaries, while the dictionaries used for the analysis of the English lexemes, in order to obtain as much information as possible, belong to the categories of the so-called collegiate and unabridged dictionaries. And fourth, language is a living form and each individual's contribution to it might result in an acknowledged change.

\section{Internationalisms Beginning with the Letter L - A Classification}

According to Ivir (1988), there are "three possible types of semantic relationship between an internationalism in one language and its counterpart in another language: full overlap, partial overlap, and no overlap" (Ivir 1988: 96).

When comparing the Slovene lexemes with their English counterparts in order to establish whether any differences, in form and/or meaning, may be observed, only 84 lexical pairs, which equals 9.38 per cent of the corpus, have been classified as true friends. ${ }^{6}$

With the exception of liftboy, lineation, localism, logograph and lotion, true friends seem to be restricted to subject fields, e.g., music, ${ }^{7}$ religion (labarum v. labarum, lama v. lama, limbo v. limbo), biochemistry and chemistry (lipid v. lipid, lipoid v. lipoid, lupulin v. lupulin), or are rarely used (lavacija v. lavation, letargija v. lethargy, lunacija v. lunation). See Figure 2.

the letter A in the above-mentioned dictionary exceeds by far the number given by Pregelj. Another objection to her analysis might be that her comparison and classification are based on the differences found when consulting the Slovar slovenskega knjižnega jezika for the Slovene language and Oxford Advanced Learner's Dictionary (1989) for the English language (cf. Pregelj 1995: 15). While the former is a monolingual dictionary for native speakers, the latter is intended for foreign-language learners. Since they cater for different dictionary users, the type and amount of information is different as well (cf. Hartmann 1983, 1992, Cowie 1987 and 1990, Landau 1989, Svensén 1993). The results of Pregelj's analysis would probably be different if she had consulted two monolingual dictionaries for native speakers.

${ }^{6}$ The results can be supported also by the findings of Alan Partington. In his 1993 article, Partington concludes that "there is tentative evidence to suggest, then, that the number of wholly reliable true friends between even closely related languages is probably fewer than is generally imagined" (Partington 1993: 109).

${ }^{7}$ Out of 84 true friends, $12(14.3 \%)$ are restricted to music (lamento, lamentoso, larghetto, largo, leggero, lentamente, lento).

${ }^{8}$ The semantic analysis did not comprise zero-equivalent false friends for the simple reason that the English language lacks the counterpart with which the Slovene internationalisms could be compared. Since 115 zero-equivalent false friends were found in the corpus, the analysis was carried out on a sample of 780 Slovene internationalisms and their English counterparts. 


\section{Figure 2. Slovene-English true friends beginning with the letter $\mathrm{L}$}

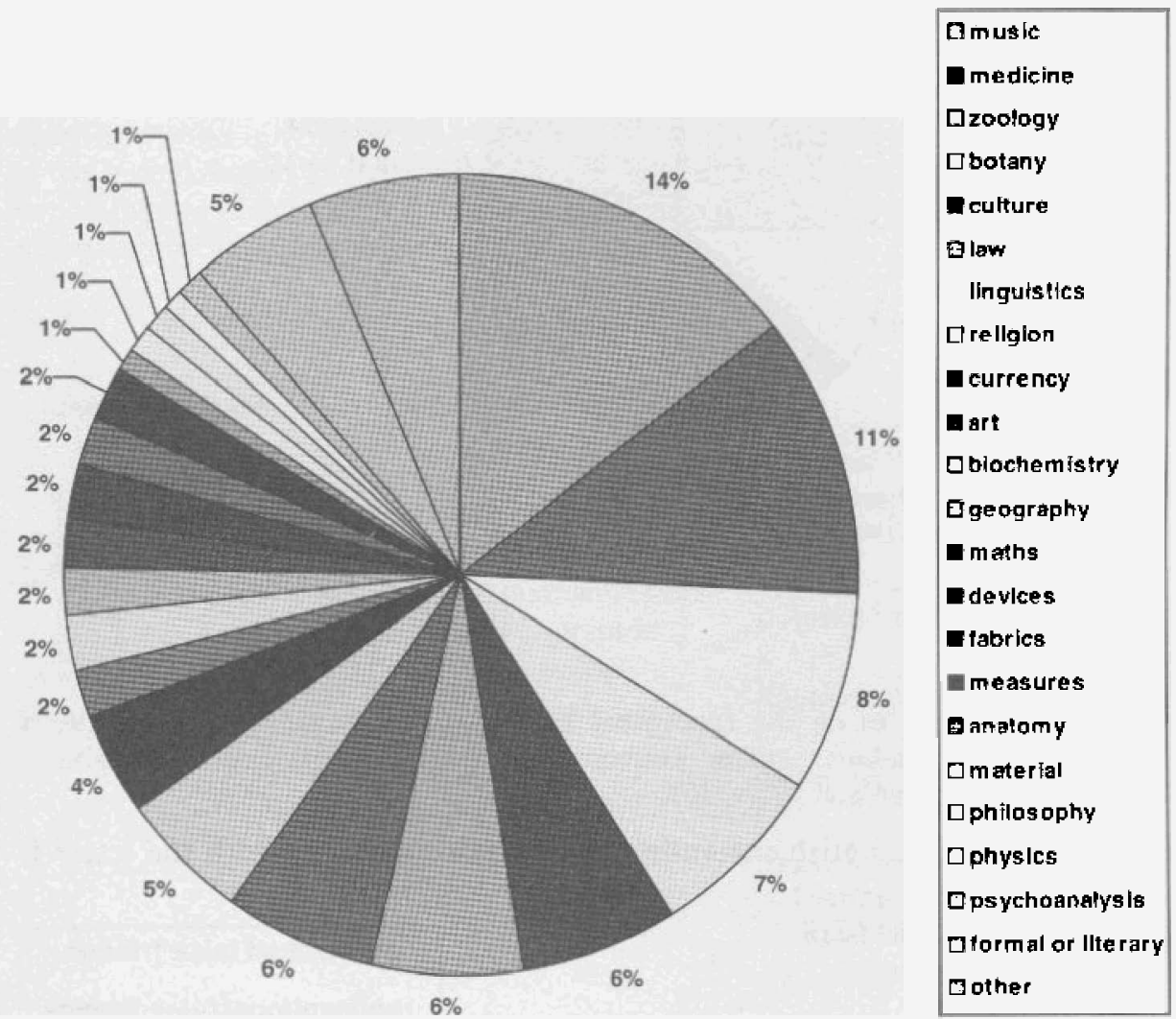

A careful examination of the semantic content of the Slovene-Enelish lextcal pairs" showed that, on the conceptual level (and maybe on other semantic levels as well), 45 pairs of lexenes do not overlap at all, while 134 pairs of internationalisms ovetlap only partially. Out of these 134 cases of parlial false friendship, the Slovene lexical item is narrover in meaning than its English counterpart (L1 $<$ L2) in 78 instances (laburisticen $v$, labour/Labour, licenca $v$. licence and liker $v$. liqueur), there ate 37 cases in which the Slovene lexeme is broder in meaning than its English counterpart ( $\mathrm{L} 1>\mathrm{L} 2$ ) (levit $\mathrm{v}$, Levite, Imonara $\mathrm{v}$, lemonade, luminal $\mathrm{v}$. Luminan), while 19 lexical pairs are at the same time broader and narrower in meaning ( $\mathrm{L} 1<\mathrm{L} 2)$, e.g. lazaret v. lazarettollazaretlazarente, limu-ina v. limousine and losa y. loge. See Figure 3. 
Figure 3. Slovene-English conceptual false friends beginning with the letter L

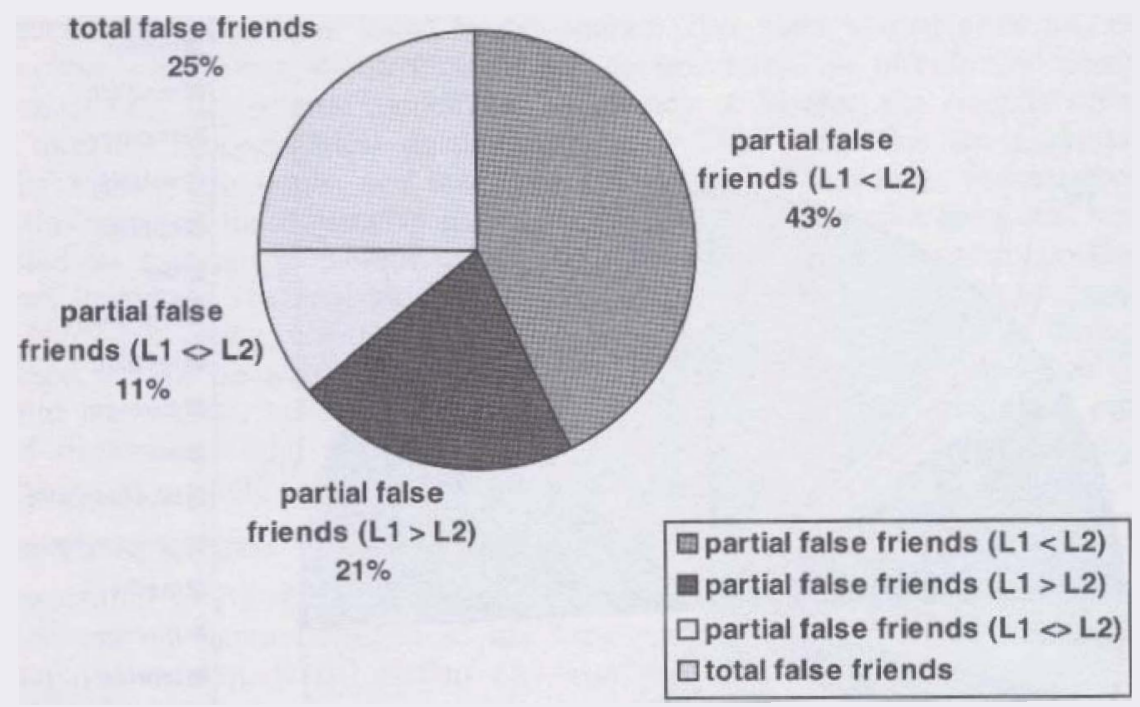

Often divergences on the conceptual level are accompanied by differences on the stylistic, collocational and/or connotational level as well, e.g., laborirati $v$. labour, lak v. lacquer and lift v. lift.

Figure 4. Slovene-Englinh semantic fale friends beginning with the letter L

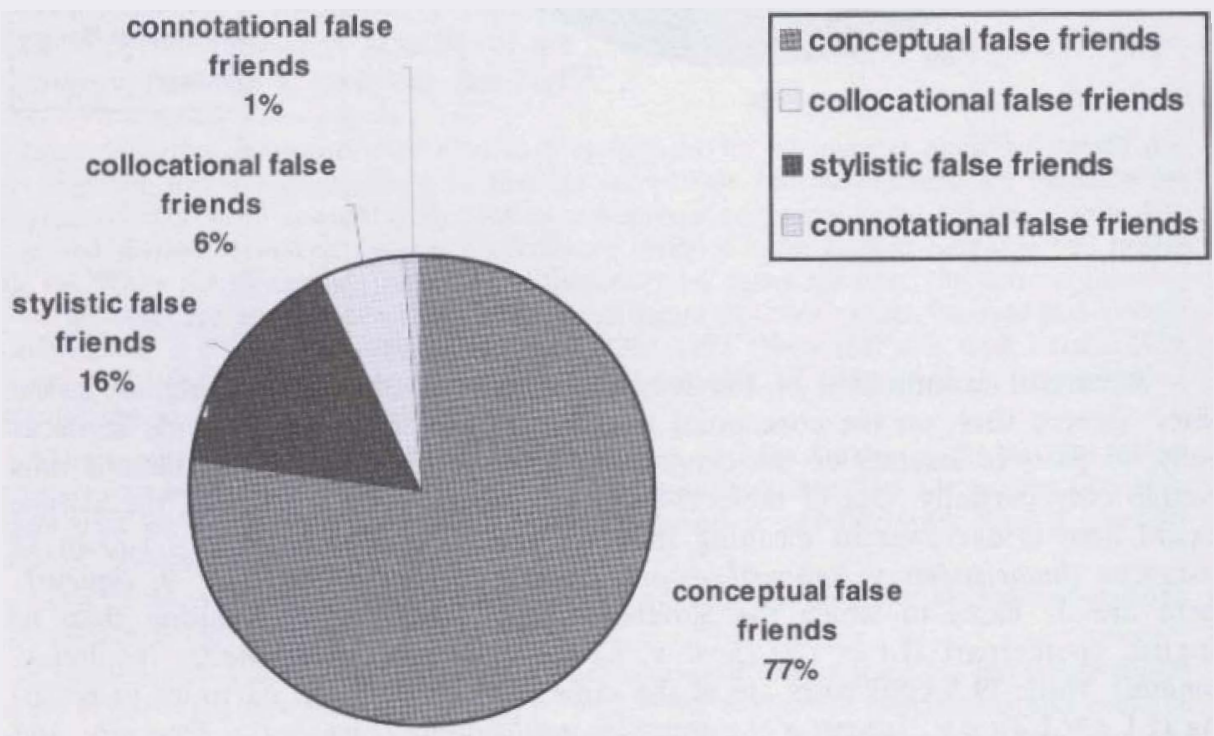


Apart from the above-mentioned semantic false friends, differences in the stylistic meaning resulted in false friendship in 37 additional cases, 14 lexical pairs had different ranges of collocations, while 2 more pairs differed on the connotational level. In other words, 232 cases of semantic false friendship were identified.

The remaining 466 pairs of internationalisms were then compared in order to establish whether any misleading differences in form could be observed. Differences in the morphological structure result in false friendship in 236 additional cases. The corpus further consists of 184 examples of phonological false friends and 44 pairs of orthographical false friends. See Figure 5.

\section{Figure 5. Slovene-Bnglih tntertationallims beghning with the letter 1}

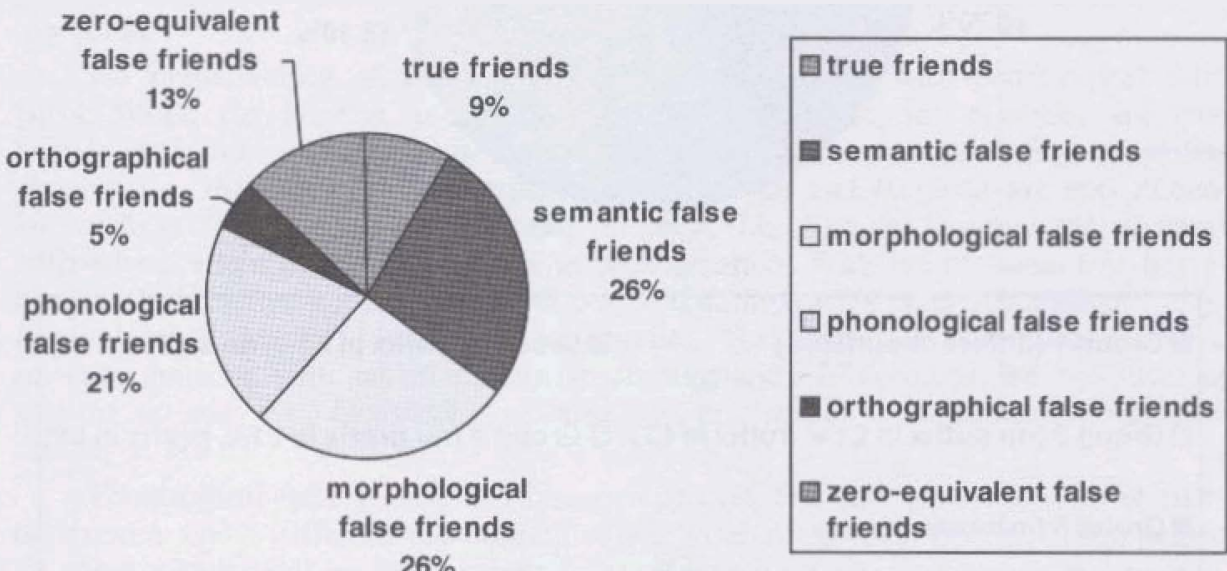

Similarly to true friends, morphological, phonological and orthographical false friends do not present any problem semantically. The errors are due to a certain similarity in form, which leads us to believe that total correspondence may exist. Most translators, lexicologists and lexicographers tend to ignore false friendship caused by dissimilarity in form. Yet, the fact that $51.7 \%$ of internationalisms beginning with the letter $\mathrm{L}$ either have a different morphological structure or are pronounced and/or spelled differently shows that this group should not be neglected.

The analysis of morphological false ftionds bowed that, on the basis of the differences in form, most of the internationaliems may be diviled into three groups; internationalisms with different suffixes (137 pairs, which mounts to $58 \%$ of morphological false frierds), internationalimo provided with a suffit in Slovene and corresponding to lexemes without any suffix in Engliah (63 pairs, which amounts to $26.7 \%$ of morphological false friends) and internatonalimu provided with a suffix in English and corresponding to lexemes without any sufix in Slovene (23 pairs, which amounts to $9.75 \%$ of morphologichl false friends). See Figure 6. 
Figure 6. Slovene-English morphological false friends beginning with the letter L

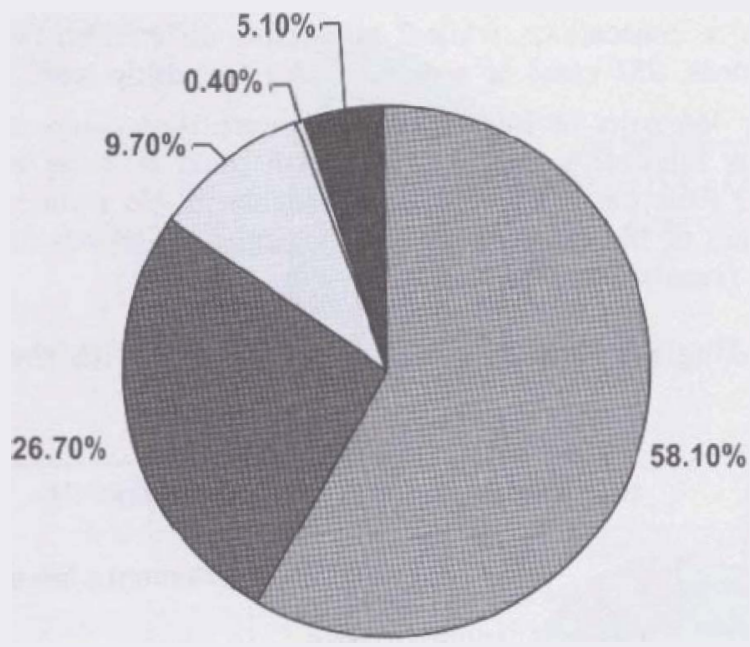

Croup 1 (dimeront sutflues)

Croup 2 (euffix in L1 v, no sufitx in (2))

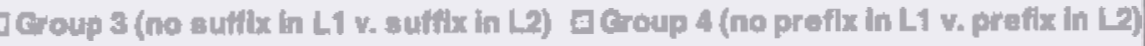

Croup 5 (miecollineous)

Although there is a very restricted, yet existent and often quoted, group of treacherous adverbs, e.g., eventualno v. eventually, evidentino v. evidently, etc., morphological false friends in the corpus of Slovene-English internationalisms beginning with the letter L do not inctude adverbs. While the noun is the prevailing part of speech in Group 1 and the only part of speech in Group 3, most of the examples in Group 2 are adjectives (71.4\%). Very often, the differences betwen Slovene and English can be explained as languages' preference for different word-formation processes (cf. Klinar 1996: 149-233).

Certain word-formation patterns seem to be predictable. When analysing internationaliams with different suffixes, for example, it could be established that all the Slovene verb ending in -zinati corresponded to Einglish verbs ending in -ise/-ize, e.g., laichirathatzhati v. latctse/laicize, legalizirati v. Legalisellegalize and leksikalizitrati se v. Lexicalise/lexicalize, while those ending in tinati tended to correspond to English verbs converted from the cortesponding nouns, or to those furnished with the zero

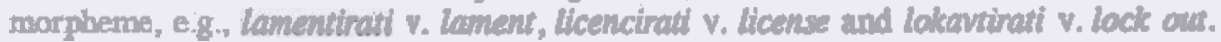

The same degree of predictability was established with Slovene nouns ending in -actja, -ocija and -ucija which all corresponded to English nouns ending in -arion, -otion and -ution (laktacija v. lactation, lokomocija v. locomotion and lokucija v. locution), with Slovene nouns ending in -izaclja and contesponding to English nouns 


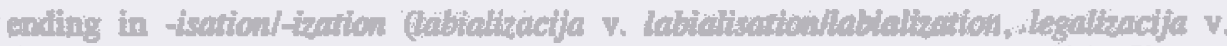

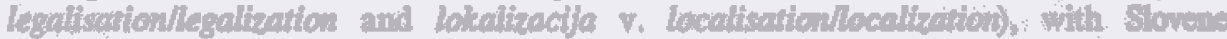

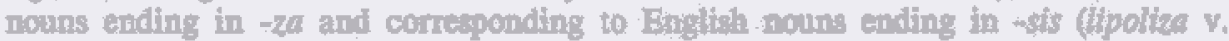

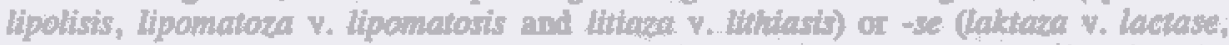

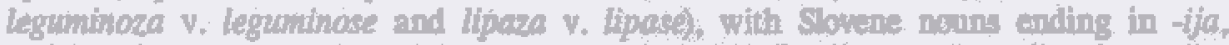

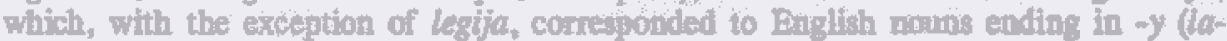
parostopla v. laporoscopy, laringalogdo vi larhyology and leksikografija v. lexico-

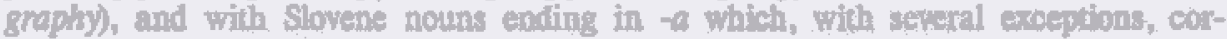
respond to English bouns ending in $-a$ (lajka v. latko, lombde $v$. lombda and lin-

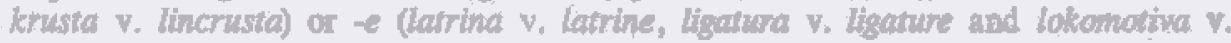
locomotive).

Becarise of a high level of predictability, the above-mentioned nowns and perbo are treated as true friends unless misleading changes in pronuncintion and/or spelling cocut.

No predictability at atl, bowever, can be estalhthed with phone'ogical false prirs. While the Sovene and English Hgrin and lupuln, for cample, are true friends and are therefore also pronounced allke - slunys condidering syatematic

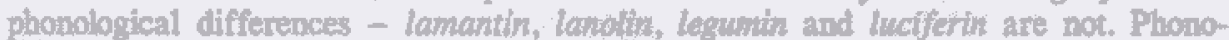
logical false friends consist of two sets of hemis. The first set is composed of items with which dissinilarity is retricted to gromanciation. With intomationalime beginning with the Letter L, 35 pairs of phonological false frimis entex this category, eq. lace, legator, teopard, howbago and luwhum. The seoond set comprises pairs of

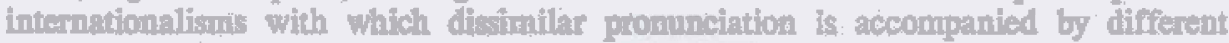

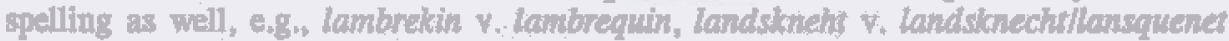
and lej $\mathrm{v}$, len.

Photnological false friends fifl into tho grous. The firt grous conists of peirs of lexemes which differ in the position of the word stress. This is ofter accompanied by other divergences in promunchation, too (lowt v. lowe, lipolka v. Lpolisis and hypanar $v$. hpanar). The second group of phondogical false friends is composed of pairs whose pronunciation differs considerably, e.g. lef $\%$. lew, loci $\mathrm{v}$. Loct and humbago v. lumbago. Sed wigute 7.

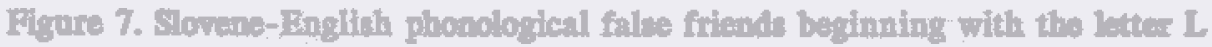

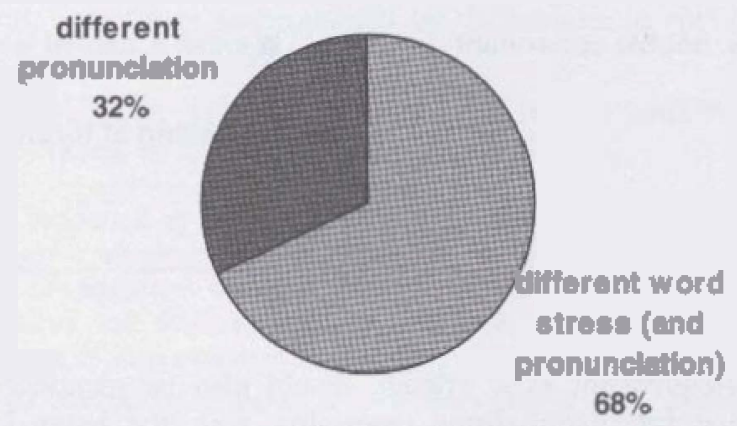

diferent word strese (and pronunclation)

adifferent pronunciation 
Orthographical false friends are pairs of internationalisms which are spelled differently, but which - apart from diferences accounted for by language systems present no problem on the phonological level. With orthographical lalse friends found in the corpus, four recurrent types of divergences may be nhserved: the use of single consonants in Slovene $v$. that of double consonants in English (lama v. llama, lema v. lemma and libreto $v$. libretto), the use of the letter $i$ in Slovene v. that of the letter $y$ in English in the orthography of lexical morphemes liabirintodont v. labyrinthodont, larinks v. larynx and lincari v. (ynch), the use of the small letter in Slovene $v$. that of the capital letter in English (Iada v. Lada, Seninist $\%$. Lenmint and $(m n i k$ v. Lumik), and differences in the spelling of a restricted number of foreign words (lazanja v. Iasagne, leitmotiv v. leitmolf and lornjer v. Iorgnetle?. See Figute 8.

Figure 8. Slovene-English orthographical false friends beginning with the letter L

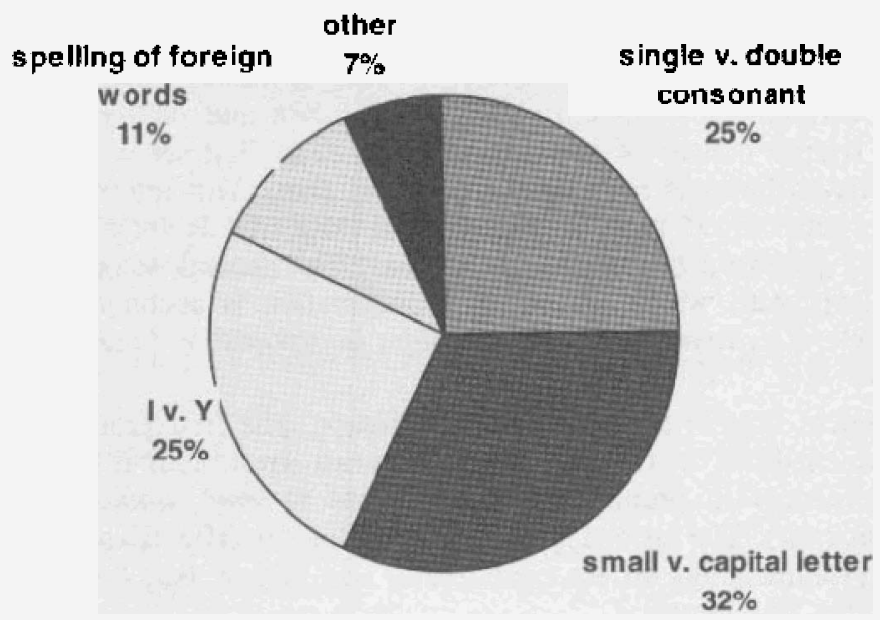

E single v. double consonant

small v. capltal letter

DIV.Y

口spelling of foreign words

Dother

Finally, zero-equivalent false friends should also be mentioned, for 12.85 per cent of the Slovene internationalisms beginning with the letter $\mathrm{L}$ belong to this category. The considerable number of zero-equivalent false friends is partly due to the incredible ease with which the Slovene language, unlike the English one, forms adjectives, and nouns denoting the quality of something and ending in -ort or stro. 
Often, Slovene zero-equivalent false friends are lexicalised in English, e.g., laksirati v. defecate. There are concepts or referents, however, which have not been lexicalised and can therefore only be paraphrased in the English language, e.g., lasalovec, which could be paraphrased as a supporter of Ferdinand Lassalle.

The results and the observations made on the basis of the described corpus analysis lead to the conclusion that false friendship is much more widespread than is generally thought.

Finally, there seems to be an interactive relationship between false friends and the user. First of all, the users, with their awareness, may prevent errors of false-friend type. ${ }^{9}$ This is undoubtedly only possible if they are provided with reliable bilingual dictionaries. ${ }^{10}$ Second, it is the users' needs that determine which type of false friends could be regarded as most treacherous. Translators and people concerned with written texts, for example, may neglect the phonological aspect of internationalisms. On the other hand, those who are interested in oral communication, for example, tourist guides, employees in international institutions, let alone interpreters, should pay special attention to differences in pronunciation as well.

\section{Conclusion}

The analysis of internationalisms beginning with the letter $\mathrm{L}$ in the Slovene language and their comparison with their English-language counterpars confirms the validity of the typology discussed by Leban 1998 according to which false friends can be divided into:

- semantic false friends, i.e., pairs of words which are identical or similar in form, but (partly or wholly) dissimilar in meaning;

- pairs of words which are identical or similar in meaning, but dissimilar in form. Three types may be established:

(a) morphological false friends, i.e., pairs of words which are identical or similar in meaning, but of different morphemic structure,

(b) phonological false friends, i.e., pairs of words with which dissimilarity in pronunciation, sometimes accompanied by differences in spelling as well, is restricted to the phonological level, and

(c) orthographical false friends, i.e., pairs of words with which dissimilarity in form is restricted to spelling;

\footnotetext{
${ }^{9}$ This has been supported by the results of an empirical study carried out by Topalova. In her 1997 article, Topalova observes that the number of errors due to false friendship decreases during the process of language learning. The merit probably goes, to a great extent, to foreign-language teachers and moderators of translation-practice classes, and their constant reminding of the existence of internationalisms and their deceptive similarities.

${ }^{10}$ Slovene-English bilingual dictionaries are not renowned for their reliability (cf. Leban 1994 and 1998, Pregelj 1995). In order to prevent errors due to false friendship, the users have to act as language and dictionary investigators. First, they must verify the existence of an internationalism in L2. Second, they ought to compare the form and the meaning(s) of the two lexemes. Third, they should find correct lexicographical equivalents.
} 
- zero-equivalent false friends, i.e., words of non-native origin whose foreign-looking and/or sounding form might induce us to believe that there exist corresponding words, identical or similar in form, in the target language, when in fact they do not.

Although the above-mentioned typology appears to be systematic, the analysis of the corpus showed that there are no clear-cut categories. The reason for this is that false friends may differ on more than one level, and that there are no clear-cut boundaries in word meaning.

\section{References}

Brown, Lesley (ed.). 1993. The New Shorter Oxford English Dictionary on Historical Principles. 2 vols. Oxford: Clarendon Press.

Cowie, Anthony (ed.). 1987. The Dictionary and the Language Learner. Papers from the EURALEX Seminar at the University of Leeds, 1-3 April 1985. Tübingen: Max Niemeyer Verlag.

Cowie, Anthony. 1990. Language as words: Lexicography. In: Collinge, N. E. (ed.). An Encyclopaedia of Language. London: Routledge, 671-700.

Cruse. D. A. 1990. Language, Meaning and Sense: Semantics. In: Collinge, N. E. (ed.). An Encyclopaedia of Language. London: Routledge, 139-171.

Crystal, David. 1987. The Cambridge Encyclopedia of Language. Cambridge: Cambridge University Press.

Dolinar, Ksenija and Seta Knop (eds.). 1994. Leksikon Cankarjeve založbe. Ljubljana: Cankarjeva založba.

Golobič, Marjan. 1988. A Glossary of Slovene-English False Friends. Ljubljana: Društvo znanstvenih in tehniških prevajalcev Slovenije.

Golobič, Marjan. 1989. Slovene-English False Friends. Slovensko-angleški nepravi prijatelji. Mostovi 24/1, 23-28.

Grad, Anton and Henry Leeming. 1990. Slovensko-angleški slovar. Ljubljana: Državna založba Slovenije.

Grad, Anton, Ružena Škerlj and Nada Vitorovič. 1992. Veliki angleško-slovenski slovar. Ljubljana: Državna založba Slovenije.

Granger, Sylviane, and Helen Swallow. 1988. False friends: a kaleidoscope of translation difficulties. Langage et l'Homme 23, 108-120.

Hartmann, R. R. K. 1983. Lexicography: Principles and Practice. London: Academic Press Inc.

Hartmann, R. R. K. 1992. Lexicography, with Particular Reference to English Learners' Dictionaries. Language Teaching 25, 151-159.

Hayward, Timothy, and André Moulin 1984. False Friends Invigorated. In: R. R. K. Hartmann (ed.). LEXeter '83 Proceedings. Lexicographics, Series Maior 1. Tübingen: Max Niemeyer, 190-198. 
Ivir, Vladimir. 1968. Serbo-Croat-English False Pair Types. Studia Romanica et Anglica Zagrabiensia 25-26, 149-59.

Ivir, Vladimir. 1988. Lexicological and Translational Treatment of Internationalisms. Folia Linguistica Acta Societatis Linguisticae Europaeae XXII/1-2, 93-102.

Klinar, Stanko (ed.). 1996. Prispevki $k$ tehniki prevajanja iz slovenščine $v$ angleščino. Teorija in praksa slovensko-angleške kontrastivne analize. Radovljica: Didakta.

Landau, Sidney. 1989. Dictionaries. The Art and Craft of Lexicography. Cambridge: Cambridge University Press.

Leban, Ksenija. 1994. Lexicological and Lexicographical Treatment of False Friends: Theoretical Considerations. Ljubljana: MA thesis.

Leban, Ksenija. 1995. Lažni prijatelji (false friends). Vestnik XXIX/1-2, 234-243.

Leban, Ksenija. 1998. Lažni prijatelji v slovensko-angleških dvojezičnih slovarjih. Mostovi 1998/XXXII, 71-75.

Leban, Ksenija. 1998. Slovensko-angleški slovar lažnih prijateljev. Ljubljana: MPhil thesis.

Limon, David. 1983. 'Nepravi prijatelji' in prevajanje iz slovenščine $\mathrm{v}$ angleščino. Vestnik 17/2, 12-25.

Makins, Marian (ed.). 1994. Collins English Dictionary. Glasgow: Harper-Collins Publishers.

Malone, Joseph L. 1982. False Friendship. Babel 28/1, 21-25.

Partington, Alan. 1993. True Friends are Hard to Find: A Machine-assisted Investigation of False, True and Just Plain Unreliable 'Friends'. Perspectives: Studies in Translatology 3:1, 99-111.

Paulin, Andrej. 1995. Tehniški metalurški slovar: slovensko-angleško-nemški. Ljubljana: Založba Mladinska knjiga.

Podobnik, Polonca. 1992. Total False Friends in Slovene and English. Ljubljana: MA thesis.

Pregelj, Magdalena. 1995. Slovene-English False Friends. Ljubljana: MA thesis.

Simpson, J. A., and E. S. C. Weiner (eds.). 1989. The Oxford English Dictionary. Second edition. Oxford: Clarendon Press.

Slovar slovenskega knjižnega jezika, 5 vols. 1970-91. Prva knjiga A-H. 1970. Druga knjiga I-Na. 1975. Tretja knjiga Ne-Pren. 1979. Četrta knjiga Preo-Š. 1985. Peta knjiga T-Ž. 1991. Ljubljana: Državna založba Slovenije.

Summers, Della (ed). 1992. Longman Dictionary of English Language and Culture. Harlow: Longman Group.

Svensén, Bo. 1993. Practical Lexicography. Principles and Methods of Dictionary-Making. Translated from Swedish by John Sykes and Kerstin Schofield. Oxford and New York: Oxford University Press.

Šega, Lidija. 1997. Veliki moderni poslovni slovar: angleško-slovenski. Ljubljana: Cankarjeva založba. 
Topalova, Antoanita. 1997. 'False friends' in Translation Work: An Empirical Study. Perspectives. Studies in Translatology 1996:2, 215-222.

Van Roey, Jacques. 1990. French-English Contrastive Lexicology: An Introduction. Serie pedagogique de l'Institut de linguistique de Louvain, 14. Leuven: Peeters and Louvain-la-Neuve: Publications Linguistiques de Louvain.

Verbinc, France. 1982. Slovar tujk. Ljubljana: Cankarjeva založba.

Wełna, Jerzy. 1977. Deceptive Words: A Study in the Contrastive Lexicon in of Polish and English. Papers and Studies in Contrastive Linguistics 7, 73-84.

Prispelo oktobra 2000, sprejeto decembra 2000

Received October 2000, accepted December 2000

\section{Internacionalizmi med slovenščino in angleščino}

Poglavitni cilj študije je bil ugotoviti, ali govorci slovenščine in angleščine lahko uporabljajo internacionalizme, besede, ki so del mednarodnega besedišča, kot lekseme, ki se pomensko povsem ujemajo $\mathrm{v}$ obeh jezikih.

$\mathrm{V}$ ta namen je avtorica pripravila korpus, ki zajema 895 slovenskih internacionalizmov na $l$ - in njihovih angleških ustreznic. Leksikalne pare je avtorica primerjala med seboj, da bi preverila, ali si izrazi ustrezajo pomensko, in sicer na konceptualni, konotacijski, kolokacijski in slogovni ravni, ter oblikovno, in sicer v morfološki sestavi, izgovarjavi in zapisu.

Rezultati študije so pokazali, da ima le omejeno število slovensko-angleških internacionalizmov dovolj skupnih semantičnih, morfoloških, fonetičnih in ortografskih lastnosti, da bi jih govorci tujega jezika lahko uporabljali v skladu s pravili maternega jezika, ne da bi v drugem jeziku naredili napako.

Pri večini preučevanih leksikalnih parov je avtorica opazila razlike v pomenu, morfološki sestavi, izgovarjavi oziroma pisavi. Pogosto so se leksikalni pari med seboj razlikovali na več ravneh. Pomenski lažni prijatelji se lahko med seboj razlikujejo na ravni pomena, morfologije, izgovarjave in pisave. Ponski lažni prijatelji se sicer pomensko ujemajo, razlikujejo pa se $\mathrm{v}$ svoji morfološki sestavi. Morfološkim razlikam se lahko pridružijo tudi razhajanja v izgovarjavi in zapisu. Glasoslovne lažne prijatelje različno izgovarjamo, včasih pa tudi zapisujemo, medtem ko so razlike med ortografskimi lažnimi prijatelji omejene zgolj na zapis.

Čeprav so internacionalizmi del mednarodnega besedišča, jih v slovenščini in angleščini ne uporabljamo na enak način. Navzlic temu nas navidezne podobnosti med njimi pogosto zavedejo, in sklepamo, da gre za lekseme, ki imajo enak pomen in se $\mathrm{v}$ jeziku podobno obnašajo, prav na podlagi takšnega sklepanja pa lahko naredimo napake in se ujamemo $\mathrm{v}$ past lažnih prijateljev.

\section{A Survey of Internationalisms between Slovene and English}

The major aim of the survey here reported was to establish whether internationalisms, words which are used internationally, may be used by Slovene and English language users as lexical items with a total meaning overlap. 
For the purpose of the study, a corpus comprising 895 Slovene lexical items beginning with the letter $\mathrm{L}$ and their English-language counterparts was created. The lexical items in the corpus were then compared to verify their similarities in meaning, both on the conceptual, connotational, collocational and stylistic levels, and in form, both in terms of their morphological structure, pronunciation and orthography.

The study showed that only a limited number of internationalisms between Slovene and English share enough semantic, morphological, phonetic and orthographic characteristics to be used in the foreign language without falling into the trap of committing interlingual errors.

With most of the analysed lexical pairs, differences in meaning, morphological structure, pronunciation and/or spelling could be observed. Often, lexical pairs differed on more than one level. Semantic false friends, for example, may differ in meaning, morphology, pronunciation and spelling. With morphological false friends, the meanings of the lexemes are the same-the lexical pairs would differ in their morphological structure. Often, morphological differences would be accompanied by phonological and orthographical divergences as well. Finally, while with phonological false friends differences in pronunciation may be supported also by different spelling, divergences among orthographical false friends are restricted to orthography.

Although it is true that internationalisms are words which are used internationally, it has been proven that they are not used in the same way in the Slovene-English language pair. Yet, it is their apparent similarities that often lead us to believe that they share their meaning and linguistic behaviour, thus inducing us to commit interlingual errors of false-friend type. 